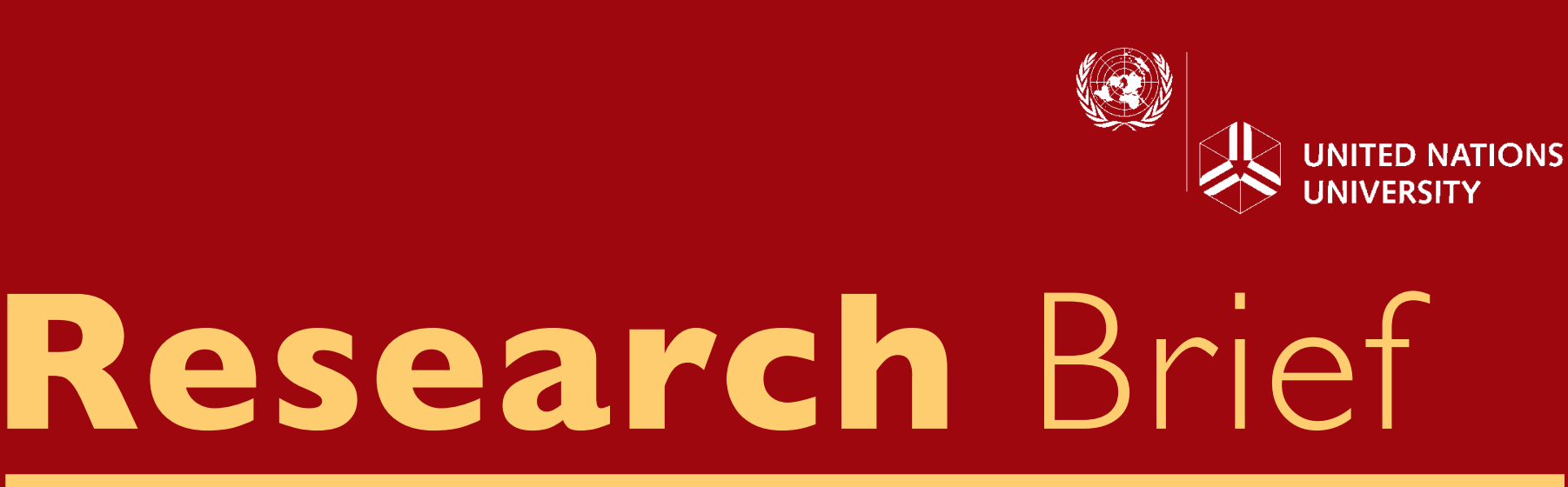

NUMBER I, 20 IO

\section{Overview}

Before the current global recession, many resource-rich African countries were recording unprecedented levels of growth due to a raw material price boom. However, the collapse in raw material prices and the ensuing severe economic difficulties have again exposed the vulnerability of these countries' natural resource export-focussed economic structures. In this research brief, we describe how Africa's abundance of natural resources attracted disruptive and predatory foreign forces that have hindered innovation-based growth and economic diversification by delaying the accumulation of sufficient stocks of human capital. We suggest that for their long-term prosperity, resource-rich African countries shift their strategic emphasis from natural to human resources and technological capabilities needed to transform those natural resources into valuable goods and services to compete in the global market.

Written by Alexis Habiyaremye and Luc Soete

(C) United Nations University, 2010

ISBN 978-92-808-3515-1

ISSN 1816-5796

Licensed under the Creative Commons Deed "Attribution-NonCommercialNoDerivs 2.5"

\title{
The Global Financial Crisis and
} Africa's "Immiserizing Wealth"

B EFORE THE ONSET OF THE CURRENT FINANCIAL crisis, some African countries richly endowed with natural resources were recording unprecedented rates of economic growth as a result of a price boom generated by the growing demand for raw materials and fossil energy from, amongst others, China and India. Almost immediately after the crisis spread to the real economy, the prices of oil and many other primary commodity items fell sharply, and reverted to their pre-boom levels. The prices of most mineral ores, in particular, declined considerably in response to the sluggish demand in international markets. The emerging optimism about Africa's growth prospects evaporated, and the usual worries about Africa's poor performance in the global economic system reclaimed their place.

The natural resource price boom that preceded the current financial crisis had reinforced in the minds of many Africans the belief that raw materials were a source of sustainable prosperity. However, when the crisis hit developed countries, the collapse of major raw material prices became inevitable, reflecting the slowdown in demand for manufactured goods and services these raw materials are used to produce. Thus, whereas most analysts expected the crisis to impact Africa only after a long period of time had passed, Africa's economy became directly and significantly hit by the decline in foreign direct investment, the contraction in credit flows and the short-fall in international remittances from its own foreign migrants. As a result, the impact of the financial crisis on African investment was much more significant and immediate than expected. This abrupt weakening of African economies, while experiencing a boom, exposed once more the vulnerability of countries that rely mainly on the export of raw materials and other primary commodities in their international trade.

As a consequence, Africa's economic future has never been as uncertain as in this period of global financial crisis, as can be inferred from the contrast between the weak and fluctuating growth rates in the period 1980-2001 and the pre-crisis boom in the period 2002-2007. Thus, the discussion on how Africa will find its way out of the current crisis inevitably reopens debates on the place of natural resources in the innovation and development process of developing countries and the longrun implications for the terms of trade of African economies as exporters of raw 
materials versus emerging countries in Asia and industrialized economies as exporters of manufactured products.

\section{Africa: A Wealthy Continent with a Poor Population}

The last two decades of the twentieth century have been marked by the economic emergence of East Asia; the beginning of the twenty-first century has witnessed the rise of China and India to the status of global economic powers with wide-ranging industrial capabilities. Real growth has been abundant natural resources is no less than a puzzle. The magnitude of this endowment can hardly be overstated and is absolutely striking. In some regions of the continent, like the Katanga province in the Democratic Republic of the Congo (DRC), the mineral wealth is so prodigiously abundant that it has sometimes been referred to as "a geological miracle". Despite this exceptional generosity of nature, the continent, in particular the Sub-Saharan region, has witnessed the lowest growth performance at the world

\section{"The contrast between Africa's tremendous 'endowment' in natural resources and its relatively weak economic performance and poor human development track record has been striking"}

significant in many East and South Asian countries from 1980 to 2007. In contrast, Africa still seems to be stuck in its natural resource and income wealth. It is as if the prodigious availability of such a natural wealth has become the main source of economic and political instability; of foreign private and public envy; and of rent-seeking behaviour in vulnerable states, with all its accompany ing features of attempts at illegal extraction. In this sense, natural resources as "the wealth of nations" are seemingly more likely to undermine a country's endogenous economic dynamism.

Since the end of the decolonization process in Africa, the contrast between Africa's tremendous "endowment" in natural resources, and its relatively weak economic performance and poor human development track record has been noteworthy. Whereas during the colonial period the basis of Africa's poor economic performance could be framed in terms of a politically imposed unequal exchange with the colonial power, today nearly half a century after independence, Africa's inability to benefit from its level, with a majority of countries remaining stuck in the group of least developed countries.

Although some observers would still affirm that Africa is a rich continent with its considerable mineral wealth, numerous communities in mineral- or oil-rich regions remain mired in misery and see little prospect of improving their livelihoods in the foreseeable future. Available evidence on the way mineral and fossil resources have been exploited so far shows that this exploitation has hindered development by preventing economic diversification and by delaying the accumulation of adequate human capital stocks needed to put the countries in question on the innovationdriven growth path. Moreover, the exploitation of natural resources in many African countries has generated conflicts and civil wars, which have impeded capital accumulation and left these countries in a self-reinforcing mechanism of dependence on the export of raw materials resulting in poverty traps. This raises the question as to whether natural resources are not the 
very root of the misery that African populations continue to experience. If this is the case, Africa's endowment in natural resources might well be termed "immiserizing wealth" by analogy to the well-known phenomenon of "immiserizing growth" in the theory of international trade.

\section{The Elusive Resource Boom, the Disruptive Forces and the Paradox of Plenty}

Prior to the commencement of the world financial crisis, the high prices of natural resources and other primary commodities in international markets had prompted many analysts to suggest that resource-rich developing countries in Africa and Latin America had eventually reached a unique opportunity to jump on a high-growth industrialization and development path. This was said to be possible if these countries succeeded in managing the revenues from their natural resources in a longterm sustainable manner by, amongst other things, investing in the creation and acquisition of new knowledge. More specifically, in the period that immediately preceded the crisis, a number of economists viewed the raw material price boom as a potentially strong counter-argument to challenge the old Prebisch hypothesis of a long-run terms of trade disadvantage for under developed countries dependent on the export of raw materials. The potentially positive role of natural resources for African future growth had become a new positive development feature as optimistic expectations based on buoyant demand seemed to have turned upside down the resource curse debate and reversed the perception of a terms of trade advantage of manufactures versus raw materials. Indeed, before the financial crisis broke out, raw material exporting countries were said to possess an enhanced comparative advantage and to face a favourable evolution of terms of trade vis-à-vis the exporters of manufactured products. Innovation and diversification into finished products were viewed as counterproductive, since raw materials were predicted to become the scarcest economic resource in the future as the fast growing Asian giants were expected to drive up the demand for such commodities for several decades.

There exists, however, a historically well-documented literature, describing in detail, on a case-by-case basis, many disruptive features of natural resource specialization within a developing country context. Across the African continent, cases of dire poverty and misery attributable to the presence of natural resources are innumerable. To name one of the most salient cases for illustration, the abundance of natural resources in the eastern provinces of DRC, instead of benefiting the Congolese population, has been one of the major sources of its misery. By igniting and fuelling the crippling wars that have plagued the country, these resources have so far cost the lives of more than five million people, and destroyed wildlife and the environment. Indeed, the huge deposits of natural resources in this nation have attracted various foreign powers, as well as internal forces that have sought to gain an easy advantage by tapping into and using mineral revenues to acquire power and finance armed conflicts. A number of major human rights groups have documented how individuals and foreign corporations have been making enormous profits from the war and have developed networks of key political, military and business elites to organize the plundering of Congo's natural resources. In October 2002, a UN expert panel accused 85 foreign companies of breaching OECD standards through their business activities connected to rape, murder,

\section{About the Authors}

Alexis Habiyaremye is a $\mathrm{PhD}$ researcher at UNU-MERIT.

Luc Soete is the director of UNU-MERIT and professor of international economic relations (on leave) at Maastricht University. 
torture and other human rights abuses that followed the scramble to exploit Congo's wealth after war broke out in 1998.

The most notorious is the trade in coltan (the ore from which tantalum, a rare mineral used in video game consoles, lap-top computers and mobile phones, is extracted) which has subjected people to conditions akin to slavery according to the same 2002 UN panel mentioned above. In 1999 and 2000, a sharp increase in the world price of tantalum led to a large increase in control of natural resources, the abundance of these "fortuitous gifts of nature", as they were referred to by Nobel Prize laureate Simon Kuznets, can hardly be perceived as contributing to economic development within a context where the resource-endowed countries merely exploit their natural wealth to export it as raw materials. Numerous cross-country studies of the impact of natural resource abundance on economic performance have unveiled that the economic performance of resource-rich countries has been poor

\section{"High shares of natural resources in the economy of a country tend to be associated with the crowding out of social and human capital"}

coltan production in eastern DRC. Part of that increased production was conducted by rebel groups and unscrupulous business people who forced farmers and their families to leave their land, or chased people off the land where coltan was found and obliged them to work in artisanal mines with hazardous levels of radiation. The resulting widespread destruction of agriculture, and the associated hunger, profoundly disrupted the social fabric of entire communities in the region. The coltan trade and battles over other resources have also affected the DRC's wildlife and environment; the national parks that house endangered gorillas and other animals are often overrun to exploit minerals and hunt wildlife. Similar examples of the harmful effects an endowment in natural resources can cause can be found in many other corners of the African continent, to say nothing of the "blood diamonds" in places such as Sierra Leone.

Even assuming away the devastating effects of violent conflicts and civil wars that arise from the scramble for the relative to that of countries without such resources.

In addition to the well-known disruptive and political dominance aspects, there are traditional economic channels through which resource endowments might hinder the longterm economic growth of a nation. These include the volatility in export revenues that hamper effective economic planning and investment; the exchange rate appreciation in periods of price booms that harm trade in other sectors; the crowding-out effects of investment capital; the underinvestment in human capital; and the lack of an employmentintensive, inclusive growth and development pattern. In general, high amounts of natural resources in the economy of a country tend to be associated with the crowding out of social and human capital, thereby impeding a pattern of more balanced economic growth and human development. This rather counter-intuitive phenomenon has been called the "paradox of plenty". Various reasons have been put forward to explain this 
puzzling poor performance of resourceabundant countries. They range from the well-known economic mechanisms to social and institutional factors inducing dysfunctional behaviour and resource misallocation.

\section{Resource Booms and Dutch Disease}

The idea that natural resources might be more of an economic liability rather than an advantage had been around since the work of Friedrich List in the nineteenth century, but began to re-emerge in the 1980s. At this time, the term "resource curse" was first used by Richard Auty, to describe how resourcerich countries were unable to use their wealth to boost their economies and how, counter-intuitively, they had lower economic growth rates than resourcescarce countries. Empirical research in this domain has hypothesized several mechanisms through which a negative relationship between natural resources and economic growth might operate. On the one hand, there are social mechanisms, which mean that resource endowment is perceived as "easy riches" which makes people lazy and prompts them to neglect education and other productive investments. Such mechanisms have a direct bearing on hindering innovation and investment in productive knowledge. On the other hand, there are purely economic and political mechanisms which imply that resource booms limit structural diversification and technology accumulation by creating opportunities for mismanage ment, rent-seeking and corruption that undermine effective spending of windfall gains. Some of the other traditional arguments to explain the paradoxical bad performance of resource-rich countries put more emphasis on the institutional aspects of the resource curse, arguing that bad economic policies correlated with resource rents are the main reasons for the poor economic performance of resource-endowed countries.

Finally, there is still a structural problem which remains as a side-effect of the resource boom. Indeed, when natural resources are exported at considerable levels (as was the case in the years preceding the financial crisis), the exporting country is ultimately not shielded from any of the indirect harmful effects. In fact, booms can indirectly harm the economy as capital and labour that would otherwise be used in the manufacturing sector are pulled into the resources sector; demand in the non-tradable sector is also increased by domestic revenues from natural resources. The increased national revenue from the booming sector also often results in higher government spending that increases the real exchange rate and raises wages.

Such booms, accompanied by a shift of resources across sectors, tend to shrink the tradable sector and hinder innovative sectors. The resource reallocation from the tradable sectors, notably agriculture and manufacturing, to the booming resources sector, makes the former less competitive in world markets. This weakening of the innovative sectors exposed to international competition results in an even greater dependence on natural resource revenue, and leaves the economy even more vulnerable to price changes in the resource sector. If the innovative manufacturing sector has externalities such as forward or backward linkages, the shrinkage of the manufacturing of tradable goods results in a chronically low growth path, as the economy loses the benefits from externalities as well as the advantages of innovation, learning effects and increasing returns to a scale that is usually associated with the manufacturing sector and often

\section{Bibliography}

Al-Marhubi, Fahim. "Export Diversification and Growth: An Empirical Investigation." Applied Economics Letters 7, no.9 (2000): 559-62.

Amin Gutiérrez de Piñeres, Sheila and Michael J. Ferrantino. Export Dynamics and Economic Growth in Latin America: A Comparative Perspective. Aldershot: Ashgate, 2000.

Auty, R. M. Resource-Based Industrialization: Sowing the Oil in Eight OilExporting Countries. Oxford: Clarendon Press; New York: Oxford University Press, 1990.

Collier, Paul. "Primary Commodity Dependence and Africa's Future" In Pleskovic, Boris and Nicholas Stern (eds). Annual World Bank Conference on Development Economics 2003:The New Reform Agenda, 139-62. Washington, D.C.: World Bank, 2003.

Collier, Paul and Anke Hoeffler."On the Incidence of Civil War in Africa." Journal of Conflict Resolution 46, no. I (2002): 13-28.

Dosi, Giovanni, Keith Pavitt and Luc Soete. The Economics of Technical Change and International Trade. London: Harvester Wheatsheaf, 1990.

ECLAC (United Nations Economic Commission for Latin America and the Caribbean). Structural Change and Productivity Growth - 20 Years Later: Old Problems, New Opportunities. Santiago: ECLAC Publications, 2008.

Essential Action. "Oil For Nothing: Multinational Corporations, Environmental Destruction, Death and Impunity in the Niger Delta." Washington D.C.: EAGE, 2000.

Gelb, Alan H. OilWindfalls: Blessing or Curse? New York: Oxford University Press, 1988.

Gylfason, Thorvaldur. "Natural Resources, Education, and Economic Development." European Economic Review 45, no. 4-6 (May 200I): 847-859.

Gylfason, Thorvaldur. "Natural Resources and Economic Growth: From Dependence To Diversification." CEPR Discussion Paper No. 4804. London: CEPR, 2004. 
nonexistent in the capital-intensive mining sector.

Through the loss of externalities, the over-valuation of the exchange rate and an increase in the wage rate, so-called "Dutch Disease" can ultimately reduce total exports relative to GNP or at least skew the composition of exports away from manufacturing and service exports that would otherwise have contributed more to economic growth. This wellknown phenomenon has occurred in countries such as Nigeria, DR Congo, Zambia and many other resource-rich specialization implies a capital-intensive rather than labour-intensive industrialization process. While the complementarity between African resources and the human capital of the colonial powers defined the economic system during the colonial period, the political independence of most African countries in the 1960s has not changed the underlying economic dependency principle. Instead of emancipating themselves from it, African countries continue to rely on the export of mineral resources to their former colonial rulers. prosperity+ In List's words, "Power is more important than wealth. And why? Simply because national power is a dynamic force by which new production resources are opened up, and because the forces of production are the tree on which wealth grows."

A perennial reliance on natural resources and other primary commodities as a development strategy is therefore problematic as it tends to confine resource-dependent countries in the illusion of "nature-given wealth" and delays investments in activities that

\section{"Weakening of the innovative sectors exposed to international competition results in an even greater dependence on natural resource revenue, and leaves the economy even more vulnerable"}

Sub-Saharan African nations, which failed to translate resource abundance into equitable and sustainable growth. For the majority of African countries, with perhaps the exception of Botswana, the abundance of natural resources appears to have been the very illustration of the "resource curse" hypothesis.

\section{Wealth and the Tree on which Wealth Grows}

Even if a country manages to avoid all the problems discussed so far, mere reliance on the export of natural resources for a country's development would remain symptomatic of a broader and more fundamental problem: the ignorance of what foreign countries produce with these raw materials, hence the total dependence of one's economic value generation on foreign value added. In most cases in Africa, resource endowments are not complementary to the typical endowment of developing countries, i.e. large human capital stocks that can add value to these resources. On the contrary, natural resource
Furthermore, the resourceexploitation system put in place during the colonial period has also left in place an education system that favoured the training of an administrative apparatus suited to manage the resource exploitation rather than to run new and complex industries that use these resources to produce finished goods. This lack of knowledge regarding how to transform raw materials is the very root of the long-run terms of trade disadvantage for primary commodity dependent countries as the price collapse at the onset of the current financial crisis reminds us. Failure to break out of that vicious circle of dependence is precisely what Friedrich List was denouncing as the source of weakness that leads to the relinquishment of powers of production, freedom and independence into the hands of those who possess more production knowledge. Failure to recognize the depth of List's message is economically suicidal because this production knowledge is ultimately the only longterm source of power to reach would help speed up the harnessing of productive knowledge. The idea that a continuous pattern of resource export is a natural outcome of factor endowment for resource-rich countries stems from a rather narrow and static interpretation of the classical trade theories of comparative advantage. According to these schools of thought, countries endowed with natural resources would be expected to naturally specialize in the export of these resources and cover their needs of other goods and services by importing them from their trade partners at mutual benefits. However, such theories remain static in their analysis; in their dynamic interpretation they lead to various forms of immiserizing wealth and other Prebisch-Singer type development traps. They also tend to ignore the important economic benefits of diversification.

\section{Conclusion}

The way the current crisis has affected the economies of resource-dependent African nations in the middle of a resource boom provides important 
lessons. Beyond the common problems associated with a dependence on natural resources, which, as argued here, make resource abundance an "immiserizing wealth" for many African countries, the current financial crisis reopened the debate on the long-run terms of trade of raw materials. Being characterized by derived demand, raw materials are at best only transitory wealth which by themselves are incapable of bringing lasting prosperity to a nation. That is why the illusion of wealth created by a rich endowment of natural resources has hindered many African countries in their attempts to develop. As a result of its continued reliance on the export of raw materials, Sub-Saharan Africa missed out on the benefits associated with the tremendous expansion of the world economy and increased productivity of the post-World War II period in various parts of the world because these productivity gains occurred primarily in the manufacturing sector. At the same time, a handful of resource-scarce countries in East Asia have engaged in large-scale manufacturing and managed to close the income gap and to converge towards industrialized countries' productivity levels.

In contrast to the belief that Africa's future prosperity lies in properly managing resource revenues while ignoring what others do with its raw materials, we argue that only productive knowledge can allow resource-rich Africa to emerge from its current state of poverty and assume a meaningful place in a global competitive system. One of the biggest development challenges for Africa is to emancipate its economies from the dependence on natural resources by betting on the gradual accumulation of productive and innovative knowledge. Such innovative knowledge must be geared towards economic diversification into productive activities that will enable it to efficiently use its resources to produce valuable goods and services that can compete in the global markets. The education system inherited from the colonial period is in many instances inadequate for tackling the current challenges of acquiring the needed productive knowledge because that system was oriented towards resource exploitation.

For most African countries, technological capability building requires a reassessment of the adequacy of their whole education system and an adaptation of the curricula offered by their universities and those followed by their nationals sent to study in developed countries with respect to the need to acquire technology-related knowledge. For example, instead of the current disproportionate share of students focussing on literature, philology and other philosophical disciplines, the curricula should reflect this need for a purposeful acquisition of specific knowledge, directly applicable to the creation or expansion of productive power.
Gylfason, Thorvaldur and Gylfi Zoega.

"Natural Resources and Economic Growth:The Role of Investment." CEPR Discussion Paper No. 2743. London: CEPR, 200I.

Habiyaremye, Alexis. "Dependence on Primary Commodities and Poverty Traps in Sub-Saharan Africa: Devising strategies and building capabilities for diversification." UNU-INTECH Discussion Paper Series No. 2005-09 (2005).

Habiyaremye, Alexis. From Primary Commodity Dependence to Diversification and Growth:Absorptive Capacity and Technological Catch Up in Botswana and Mauritius. Saarbrücken, Germany: VDM Verlag, 2009.

Kaplinsky, Raphie." "The Challenge of Asian Drivers: From Industrial to Innovation Policy." Charles Cooper Annual Lecture (UNU-MERIT, Maastricht, 19 January 2007).

Kuznets, Simon. "Modern Economic Growth: Findings and Reflections." Lecture to the Memory of Alfred Nobel (II December 197I).

List, Friedrich. Das nationale System der politischen Ökonomie. Bd. I. Stuttgart and Tübingen, 184I.

Matsuyama, Kiminori.“Agricultural productivity, comparative advantage and economic growth." Journal of Economic Theory 58, no. 2 (December 1992): 317-334.

Perez, Carlota. "AVision for Latin America:A Resource-based Strategy for Technological Dynamism and Social Inclusion." Paper prepared for the ECLAC Program on Technology Policy and Development in Latin America. Santiago: ECLAC, July 2008.

Robinson, James A., Ragnar Torvik and Thierry Verdier." "Political Foundations of the Resource Curse." Paper prepared for the conference to celebrate Pranab Bardhan's tenure as editor of the Journal of Development Economics (9 May 2005).

Sachs Jeffrey D. and Andrew M.Warner. "Natural Resource Abundance and Economic Growth." Center for International Development and Harvard Institute for International Development (November 1997). 


\section{www.merit.unu.edu}

\section{UNITED NATIONS UNIVERSITY}

\section{UNU-MERIT}

UNU-MERIT is the United Nations University Maastricht Economic and social Research and training centre on Innovation and Technology. It integrates the former UNU Institute for New Technologies (UNUINTECH) and the Maastricht Economic Research Institute on Innovation and Technology (MERIT). UNU-MERIT provides insights into the social, political and economic contexts within which innovation and technological change is created, adapted, selected, diffused, and improved upon. The Institute's research and training programmes address a broad range of relevant policy questions dealing with the national and international governance of innovation, intellectual property protection, and knowledge creation and diffusion. UNU-MERIT is located at, and works in close collaboration with, Maastricht University in The Netherlands.

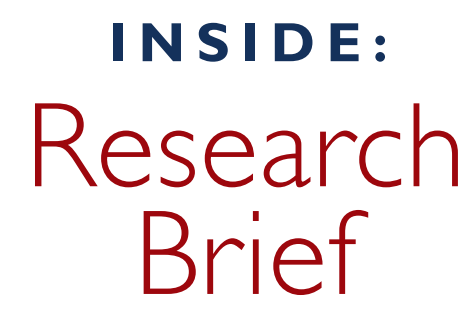

The Global Financial

Crisis and Africa's "Immiserizing Wealth"

Only productive knowledge can allow resource-rich Africa to emerge from the current state of poverty and assume a meaningful place in a global competitive system.

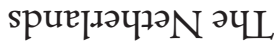

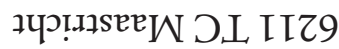

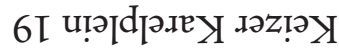

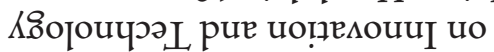

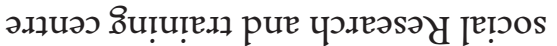

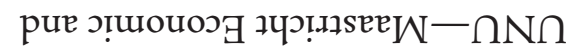

\section{니W-กNก}

ALISYGAINO SNOILYN GJIINก 